No 4078

Studia nad Autorytaryzmem i Totalitaryzmem 43, nr 4 Wrocław 2021

https://doi.org/10.19195/2300-7249.43.4.3

\author{
DOMINIKA CENDROWICZ \\ ORCID: 0000-0002-2358-7188 \\ Uniwersytet Wrocławski \\ dominika.cendrowicz@uwr.edu.pl
}

\title{
Regulacja prawna pomocy społecznej w Polsce w okresie powojennym do 1989 roku
}

Slowa kluczowe: pomoc społeczna, świadczenia pieniężne, PRL, socjalizm, autorytaryzm.

\author{
LEGAL REGULATION OF SOCIAL WELFARE IN POLAND \\ IN THE POST-WAR PERIOD UP TO 1989
}

\begin{abstract}
The article's aim is to examine the legal regulation of social welfare in Poland after World War II up to the year 1989. The article analyzes the legal position of beneficiaries of social welfare benefits in that period. The political situation in Poland after the end of World War II introduced changes in the perception of the pre-war system of social welfare. In the period of the Polish People's Republic, social welfare was based on an incorrect legal basis and the legal position of beneficiaries of social welfare was not protected by law. Social welfare was transferred to the Ministry of Health and its organizational system was centralized. Such a situation lasted until the Act of 29 November 1990 on Social Welfare was passed. Theoretical and historical methods of legal research were used in this article.
\end{abstract} tarianism.

Keywords: social welfare, monetary benefits, Polish People's Republic, socialism, authori-

\section{Wprowadzenie}

Pomoc społeczna to doniosła sfera działalności administracji publicznej i ważna instytucja polityki społecznej państwa ${ }^{1}$. Jej regulacja prawna znajduje się obecnie

1 Zob. S. Nitecki, Prawo do pomocy spolecznej w polskim systemie prawnym, Warszawa 2008, passim.

Studia nad Autorytaryzmem i Totalitaryzmem 43, nr 4, 2021

(C) for this edition by CNS 
w ustawie z dnia 12 marca 2004 roku o pomocy społecznej ${ }^{2}$. Zgodnie z tą ustawą pomoc społeczna stanowi instytucję polityki społecznej państwa mającą na celu umożliwienie osobom i rodzinom przezwyciężanie trudnych sytuacji życiowych, których nie są one w stanie pokonać przy użyciu własnych uprawnień, zasobów i możliwości (art. 2 ust. 1 u.p.s.). Ważną rolę w systemie organizacyjnym pomocy społecznej odgrywa gmina będąca podstawowym podmiotem administracji świadczącej $^{3}$. Zanim jednak pomoc społeczna uzyskała swój obecny kształt w prawie krajowym, przeszła długą ewolucję

od nawiązania do postępowych tradycji okresu międzywojennego, poprzez okres jej negacji, jako urządzenia ustrojowo obcego, fazę stopniowego uznawania jej roli w warunkach państwa socjalistycznego, aż do przyznania jej pozycji ważnego i niezbędnego ogniwa w systemie urządzeń służących zaspokajaniu ważnych potrzeb człowieka ${ }^{4}$.

W drugiej połowie ubiegłego stulecia zasadniczy wpływ na ewolucję pomocy społecznej miały przemiany ustrojowe zapoczątkowane w Polsce po zakończeniu II wojny światowej ${ }^{5}$. Opisując pomoc społeczną w prawie krajowym w okresie powojennym do 1989 roku, można wyróżnić następujące fazy jej rozwoju: 1. okres ratunkowy obejmujący czas bezpośrednio po zakończeniu II wojny światowej; 2. okres zastoju opieki społecznej w okresie stalinizmu; 3. okres ponownego rozwoju tej instytucji po 1958 roku$^{6}$. W literaturze spotkać można również klasyfikację obejmującą lata 1948-1956, w których podejmowane były próby likwidacji przedwojennej instytucji opieki społecznej, a także okres po 1956 roku, kiedy nastąpiło jej powolne odradzanie się w warunkach ustroju państwa socjalistycznego ${ }^{7}$.

\section{W kwestii nazewnictwa pomocy społecznej w okresie PRL}

Wprowadzane po 1945 roku zmiany w zakresie treści przedwojennej instytucji opieki społecznej przyniosły zmianę jej nazewnictwa. Komisja Socjalna przy $\mathrm{KC} \mathrm{PZPR}^{8}$ uznała, że ustrój socjalistyczny nie likwiduje potrzeby istnienia opieki

${ }^{2}$ Ustawa z dnia 12 marca 2004 roku o pomocy społecznej (Dz.U. z 2020 r. poz. 1876 ze zm., dalej: u.p.s.).

3 I. Lipowicz, Samorzad terytorialny jako podmiot administracji świadczacej, „Ruch Prawniczy, Ekonomiczny i Socjologiczny” 2015, z. 3, s. 117.

${ }^{4}$ H. Szurgacz, Wstęp do prawa pomocy społecznej, Wrocław 1992, s. 12.

5 Zob. H. Szurgacz, Uwagi o ewolucji pomocy społecznej, „Praca i Zabezpieczenie Społeczne" 1987, nr 2 .

${ }^{6}$ K. Kluzowa, Historia pracy socjalnej na łamach „Pracy Socjalnej”, [w:] Z zagadnień historii pracy socjalnej w Polsce, red. A. Małek, K. Slany, I. Szczepaniak-Wiech, Kraków 2006, s. 64-66.

7 M. Brenk, System opieki społecznej w okresie Polski Ludowej (lata 1944-1989). Zarys problematyki, „Biuletyn Historii Wychowania” 2017, nr 37, s. 80.

8 Chodzi o Komitet Centralny Polskiej Zjednoczonej Partii Robotniczej. 
społecznej, ale zmienia rodzaj potrzeb zgłaszanych do zaspokojenia w jej ramach przez obywateli oraz zakres i formy udzielanej pomocy ${ }^{9}$. Przyjęto, że w państwie socjalistycznym, które gwarantuje wszystkim obywatelom pracę, nie ma miejsca na ubóstwo, bezdomność czy bezrobocie. Opieka społeczna jest więc nieprzydat$\mathrm{na}^{10}$. Od chwili uchwalenia Konstytucji PRL z dnia 22 lipca 1952 roku $^{11}$ nastąpiło utrwalenie pojęcia pomocy społecznej w miejsce opieki społecznej. Zmiana nazewnictwa podyktowana została zmianami w materialnej treści opieki społecznej i względami natury politycznej, ponieważ pojęcie opieki społecznej powstało i używane było w okresie międzywojennym ${ }^{12}$. W wielu aktach prawnych tamtego okresu nadal spotkać można było jednak pojęcie opieki społecznej, jak na przykład w ustawie z dnia 13 kwietnia 1960 roku o utworzeniu Komitetu Pracy i Płac i o zmianie właściwości w dziedzinie ubezpieczeń społecznych i opieki społecznej ${ }^{13}$ czy w ustawie z dnia 20 lipca 1983 roku o systemie rad narodowych i samorządu terytorialnego ${ }^{14}$.

Opieka społeczna ukształtowana została w Polsce przed II wojną światową ustawą z dnia 16 sierpnia 1923 roku o opiece społecznej ${ }^{15}$. Zgodnie z tą ustawą mianem opieki społecznej określano zaspokajanie ze środków publicznych niezbędnych potrzeb życiowych osób, które trwale lub chwilowo własnymi środkami materialnymi lub własną pracą nie mogły ich zaspokoić, jak również zapobieganie powstawaniu tego rodzaju sytuacji (art. 1 u.o.s.). Rola opieki społecznej w tamtym okresie polegała na dostarczaniu niezbędnej żywności, odzieży, a także pomieszczenia, narzędzi do pracy, pomocy higieniczno-sanitarnej, pomocy w przywróceniu utraconej lub podniesieniu zmniejszonej zdolności do pracy czy też pomocy w wychowaniu dzieci ${ }^{16}$. Jej charakterystyczną cechą było doraźne, okresowe lub trwałe dostarczanie środków niezbędnych dla utrzymania jednostki przy równoczesnym przejęciu odpowiedzialności za jej los ${ }^{17}$. Tym samym opieka społeczna

${ }^{9}$ P. Sałustowicz, Pomoc społeczna w wybranych krajach Unii Europejskiej, Warszawa 2009, s. 16.

10 M. Karczewski [bez tytułu], „Opiekun Społeczny” 1974, nr 2, s. 9.

11 Konstytucja Polskiej Rzeczypospolitej Ludowej uchwalona przez Sejm Ustawodawczy w dniu 22 lipca 1952 roku (Dz.U. z 1952 r. Nr 33, poz. 232, dalej: Konstytucja PRL).

12 A. Kokoszkiewicz, Opieka społeczna jako zadanie państwa. Studium teoretycznoprawne, Lublin 2015, s. 24.

13 Ustawa z dnia 13 kwietnia 1960 roku o utworzeniu Komitetu Pracy i Płac i o zmianie właściwości w dziedzinie ubezpieczeń społecznych i opieki społecznej (Dz.U. z 1960 r. Nr 20, poz. 119, dalej: u.k.p.p.).

14 A. Miruć, O istocie pomocy społecznej, „Administracja. Teoria. Dydaktyka. Praktyka” 2006, nr 4 (5), s. 26.

15 Ustawa z dnia 16 sierpnia 1923 roku o opiece społecznej (Dz.U. z 1923 r. Nr 92, poz. 726, dalej: u.o.s.).

16 J.S. Langrod, Praca i ubezpieczenia spoteczne, [w:] K.W. Kumaniecki, J.S. Langrod, S. Wachholz, Zarys ustroju, postępowania i prawa administracyjnego w Polsce, Kraków-Warszawa 1939, s. 441.

17 K. Stopka, Zasada subsydiarności w prawie pomocy społecznej, Warszawa 2009, s. 54. 
opierała się na metodzie udzielania pomocy charakterystycznej dla dobroczynności ${ }^{18}$. Jej zastąpienie instytucją pomocy społecznej motywowane było w PRL chęcią ukazania jakościowej różnicy w zakresie wprowadzanego w jej miejsce modelu pomocy społecznej ${ }^{19}$, który w odróżnieniu od opieki ukierunkowany został na aktywizację jej świadczeniobiorców ${ }^{20}$.

\section{Regulacja prawna pomocy społecznej w latach 1947-1956}

W pierwszych latach po II wojnie światowej opieka społeczna w Polsce spełniała funkcję ratownictwa społecznego i koncentrowała się na zaspokajaniu elementarnych potrzeb ludności ${ }^{21}$. W latach 1945-1947 działania opiekuńcze podejmowane były bez skonkretyzowanej podstawy prawnej ${ }^{22}$. Dopiero moca art. 1 dekretu z dnia 22 października 1947 roku w sprawie mocy obowiązującej niektórych przepisów ustawodawstwa $\mathrm{z}$ zakresu opieki społecznej ${ }^{23}$ rozciągnięto na całym obszarze Polski moc obowiązującą u.o.s. oraz między innymi:

— $§ 1,5,6$ i 7 rozporządzenia Prezydenta Rzeczypospolitej Polskiej z dnia 29 czerwca 1924 roku w sprawie wykonywania opieki społecznej nad obywatelami polskimi, którzy w żadnej gminie Rzeczypospolitej Polskiej nie mają prawa do opieki trwałej, oraz ponoszenia wynikających stąd kosztów ${ }^{24}$;

— rozporządzenia Prezydenta Rzeczypospolitej z dnia 6 marca 1928 roku o rozgraniczeniu obowiązków opiekuńczych związków komunalnych ${ }^{25}$;

— rozporządzenia Prezydenta Rzeczypospolitej z dnia 14 października 1927 roku o zwalczaniu żebractwa i włóczęgostwa ${ }^{26}$;

— rozporządzenia Prezydenta Rzeczypospolitej z dnia 6 marca 1928 roku o opiekunach społecznych i o komisjach opieki społecznej ${ }^{27}$.

18 Ibidem.

19 Ibidem, s. 55.

20 I. Sierpowska, Prawo pomocy społecznej, Warszawa 2011, s. 18-19.

21 K. Stopka, op. cit., s. 55.

22 M. Mincer, Pomoc społeczna jako instytucja prawna, „Nowe Prawo” 1983, nr 1, s. 28.

23 Dekret z dnia 22 października 1947 roku w sprawie mocy obowiązującej niektórych przepisów ustawodawstwa z zakresu opieki społecznej (Dz.U. z 1947 r. Nr 65, poz. 389).

24 Rozporządzenie Prezydenta Rzeczypospolitej Polskiej z dnia 29 czerwca 1924 roku w sprawie wykonywania opieki społecznej nad obywatelami polskimi, którzy w żadnej gminie Rzeczypospolitej Polskiej nie mają prawa do opieki trwałej, oraz ponoszenia wynikających stąd kosztów (Dz.U. z 1934 r. Nr 56, poz. 576).

${ }^{25}$ Rozporządzenie Prezydenta Rzeczypospolitej z dnia 6 marca 1928 roku o rozgraniczeniu obowiązków opiekuńczych związków komunalnych (Dz.U. RP z 1928 r. Nr 26, poz. 232).

${ }^{26}$ Rozporządzenie Prezydenta Rzeczypospolitej z dnia 14 października 1927 roku o zwalczaniu żebractwa i włóczęgostwa (Dz.U. RP z 1927 r. Nr 92, poz. 823).

27 Rozporządzenie Prezydenta Rzeczypospolitej z dnia 6 marca 1928 roku o opiekunach społecznych i o komisjach opieki społecznej (Dz.U. RP z 1928 r. Nr 29, poz. 267). 
W analizowanym okresie z opieki społecznej wyłączono sprawy związane z opieką nad dziećmi do lat trzech i nad kobietami ciężarnymi i karmiącymi, które to sprawy włączono do zakresu działania Ministra Pracy i Opieki Społecznejer. Momentem kluczowym w zakresie centralizacji systemu organizacyjnego opieki społecznej stała się likwidacja samorządu terytorialnego. Przepisem art. 32 ustawy z dnia 20 marca 1950 roku o terenowych organach jednolitej władzy państwowej ${ }^{29}$ zniesiono w Polsce związki samorządu terytorialnego. Dotychczasowe obowiązki gmin wiejskich i miejskich, jak również powiatowych związków samorządowych w zakresie opieki społecznej przeszły na organy administracji terytorialnej stopnia podstawowego, zaś zadania wojewódzkich związków samorządowych zostały przejęte przez organy administracji terytorialnej stopnia wojewódzkiego ${ }^{30}$. Nastąpiła tym samym centralizacja systemu organizacyjnego pomocy społecznej, przełamana dopiero w 1990 roku wraz z restytucją samorządu terytorialnego na stopniu gminy i uchwaleniem ustawy z dnia 29 listopada 1990 roku o pomocy społecznej.

Istotnym etapem ewolucji opieki społecznej w PRL było uchwalenie 22 lipca 1952 roku Konstytucji PRL, która odwoływała się do instytucji pomocy społecznej $\mathrm{w}$ art. 60 ust. 2 pkt $1 \mathrm{i}$ traktowała ją jako formę urzeczywistniania prawa obywateli do ochrony zdrowia i prawa do pomocy w razie choroby lub niezdolności do pra$\mathrm{cy}^{31}$. Podstawę prawną do udzielania innych form świadczeń socjalnych na gruncie Konstytucji PRL wyprowadzano również z art. 69 (prawo do wypoczynku), art. 72 (prawo do nauki), art. 80 (opieka nad młodzieżą) ${ }^{32}$. W art. 14 Konstytucji PRL wyrażona została zasada: „od każdego według jego zdolności, każdemu według jego pracy"33. Nowe nazewnictwo w zakresie pomocy społecznej podyktowane było głównie względami politycznymi i stało się adekwatne do zmian, które zachodziły w systemie opieki społecznej od początku lat sześćdziesiątych ubiegłego wieku ${ }^{34}$.

\section{Regulacja prawna pomocy społecznej w latach 1956-1989}

W 1958 roku Komisja Socjalna przy KC PZPR opracowała program zmierzający do kompleksowego działania w pomocy społecznej. Dalsze działania w zakresie

28 Nastąpiło to na mocy art. 1 ustawy z dnia 4 lutego 1950 roku o przekazaniu Ministrowi Zdrowia zakresu działania Ministra Pracy i Opieki Społecznej w przedmiocie opieki społecznej nad dziećmi do lat trzech oraz nad kobietami ciężarnymi i karmiącymi (Dz.U. z 1950 r. Nr 6, poz. 49).

29 Ustawa z dnia 20 marca 1950 roku o terenowych organach jednolitej władzy państwowej (Dz.U. z 1950 r. Nr 14, poz. 130).

30 D. Cendrowicz, Sytuacja administracyjnoprawna adresata świadczeń z zakresu pomocy społecznej, Wrocław 2017, s. 124-125.

31 M. Mincer, op. cit., s. 81.

32 Ibidem.

33 Cytat ten pochodzi z pracy K. Marksa Krytyka programu gotajskiego z 1891 roku.

34 K. Stopka, op. cit., s. 56. 
pomocy społecznej objęły między innymi wydanie przez Radę Ministrów uchwały $\mathrm{nr} 92 \mathrm{z}$ dnia 5 marca 1959 roku w sprawie powołania instytucji opiekunów społecznych $^{35}$. Mocą jej § 1 postanowiono, że w organach właściwych do spraw pomocy społecznej prezydiów powiatowych (miejskich w miastach stanowiących powiaty miejskie i dzielnicowych w miastach wyłączonych z województw) rad narodowych należy powołać powiatowych (miejskich, dzielnicowych) opiekunów społecznych przewidzianych w rozporządzeniu Rady Ministrów z dnia 9 maja 1958 roku w sprawie ustalenia stanowisk, kwalifikacji i uposażenia pracowników prezydiów rad narodowych ${ }^{36}$. Następnie wydane zostało zarządzenie Ministra Pracy i Opieki Społecznej z dnia 27 października 1959 roku o zakresie i trybie działania opiekunów społecznych ${ }^{37}$, które w $§ 1$ stanowiło, że

powiatowi (miejscy, dzielnicowi) opiekunowie społeczni działają w organach właściwych do spraw pomocy społecznej prezydiów powiatowych (miejskich w miastach stanowiących powiaty miejskie i dzielnicowych w miastach wyłączonych z województw) rad narodowych.

Jeśli chodzi o umiejscowienie opieki społecznej w systemie organizacyjnym ówczesnej administracji państwowej, należy wskazać, że do 1960 roku naczelnym organem administracji państwowej w zakresie opieki społecznej był Minister Pracy i Opieki Społecznej. Urząd Ministra Pracy i Opieki Społecznej został jednak zniesiony na mocy art. 13 ust. 1 u.k.p.p. Na mocy art. 13 ust. 3 u.k.p.p. nastąpiła zaś zmiana resortowej przynależności pomocy społecznej. Właściwość Ministra Pracy i Opieki Społecznej w sprawach pomocy społecznej, zawodowej rehabilitacji inwalidów i przemysłu ortopedycznego przeszła do zakresu działania Ministra Zdrowia. Od tego momentu sprawami z zakresu pomocy społecznej zajmowały się specjalistyczne jednostki służby zdrowia. Do form pomocy, którą świadczyły, należały przede wszystkim świadczenia pieniężne, na przykład zasiłki stałe, doraźne, okresowe i jednorazowe ${ }^{38}$. Pomoc realizowana była jednak także w formie niepieniężnej i w formie opieki instytucjonalnej.

Dla pozycji prawnej świadczeniobiorców pomocy społecznej w PRL ważne znaczenie miało wydanie przez Ministra Zdrowia i Opieki Społecznej instrukcji $\mathrm{nr} 5 / 68$ z dnia 29 lutego 1968 roku w sprawie pomocy społecznej w formie świadczeń pieniężnych ${ }^{39}$. W jej treści postanowiono, że podstawę dla decyzji o udzielenia albo odmowie udzielenia świadczenia z zakresu pomocy społecznej stanowi wywiad społeczny, przeprowadzany w miejscu pobytu stałego lub czasowego oso-

35 Uchwała Rady Ministrów nr 92 z dnia 5 marca 1959 roku w sprawie powołania instytucji opiekunów społecznych (M.P. Nr 32, poz. 145).

${ }^{36}$ Rozporządzenie Rady Ministrów z dnia 9 maja 1958 roku w sprawie ustalenia stanowisk, kwalifikacji i uposażenia pracowników prezydiów rad narodowych (Dz.U. z 1958 r. Nr 33, poz. 149).

37 Zarządzenie Ministra Pracy i Opieki Społecznej z dnia 27 października 1959 roku o zakresie i trybie działania opiekunów społecznych (M.P. Nr 93, poz. 496 ze zm.).

38 D. Cendrowicz, op. cit., s. 125.

39 Instrukcja nr 5/68 Ministra Zdrowia i Opieki Społecznej z dnia 29 lutego 1968 roku w sprawie pomocy społecznej w formie świadczeń pieniężnych (Dz.Urz. MZiOS Nr 6, poz. 33 ze zm.). 
by wnioskującej o udzielenie jej pomocy społecznej ${ }^{40}$. Oprócz wskazanej instrukcji wydany został cały szereg innych aktów tego typu, jak na przykład instrukcja o pomocy w formie obiadów ${ }^{41}$ czy instrukcja w sprawie dziennych domów pomocy społecznej ${ }^{42}$. Należy podkreślić, że tego rodzaju przepisy nie stanowiły źródeł prawa powszechnie obowiązującego, a normy prawa powielaczowego.

Dopiero w 1986 roku Ministerstwo Zdrowia i Opieki Społecznej opracowało Założenia ustawy o pomocy społecznej, które zostały następnie przyjęte przez Radę Ministrów i stały się przedmiotem dyskusji odpowiedniego zespołu Rady Legislacyjnej. Zespół ten uznał, że stanowią one podstawę dla dyskusji nad kształtem przyszłej instytucji prawnej pomocy społecznej ${ }^{43}$. Zaproponowane zmiany stanowiły ważny etap na drodze do uchwalenia nowej ustawy o pomocy społecznej i zmiany jej resortowej przynależności z ministerstwa zdrowia do Ministerstwa Zdrowia do Ministerstwa Pracy i Polityki Społecznej ${ }^{44}$. Wyrazem nowych tendencji w pomocy społecznej stało się uchwalenie w 1990 roku u.p.s.d., która następnie, wielokrotnie nowelizowana, przetrwała do 2004 roku, kiedy to zastąpiona została przez obowiązującą obecnie u.p.s. Stało się to możliwe dzięki zmianom systemowym, które zaszly w Polsce po 1989 roku.

\section{Zagadnienie pozycji prawnej świadczeniobiorców pomocy społecznej w okresie PRL}

Odwołując się do zagadnienia pozycji prawnej świadczeniobiorców pomocy społecznej w PRL, należy zwrócić uwagę na kwestię podstawy prawnej udzielania świadczeń z jej zakresu przez ówczesne organy administracji państwowej. W badanym okresie obowiązywały co prawda przepisy u.o.s., jednak w praktyce nie była ona stosowana i została zastąpiona przez liczne akty prawne, z których część miała charakter aktów prawa powielaczowego, jak wspomniana instrukcja Ministra Zdrowia i Opieki Społecznej z dnia 29 lutego 1968 roku. Tego rodzaju akty prawne uzależniały przyznanie pomocy społecznej od uznania organu administracji państwowej i wyłączały możliwość sprawowania przez ówczesny Naczelny Sąd Administracyjny ${ }^{45}$ sądowej kontroli wydanych na ich podstawie decyzji o przyznaniu bądź odmowie przyznania świadczenia z zakresu pomocy społecznej. Istniejący stan rzeczy powodował, że nie było jakiejkolwiek możliwości ochrony prawnej świadczeniobiorcy przed organami administracji państwowej.

40 Wyrok NSA z dnia 30 września 1988 roku, I SA 1458/87, CBOSA.

41 Instrukcja nr 19/73 Ministra Zdrowia i Opieki Społecznej z dnia 27 lutego 1973 roku w sprawie organizowania pomocy społecznej w formie obiadów (Dz.Urz. MZiOS Nr 15, poz. 81 ze zm.).

42 Instrukcja Ministra Zdrowia i Opieki Społecznej z dnia 12 września 1979 roku w sprawie dziennych domów pomocy społecznej (Dz.Urz. MZiOS Nr 12, poz. 37).

43 H. Szurgacz, Wstep..., s. 56.

44 Ibidem, s. 57.

45 Dalej: NSA. 
W okresie PRL do powyższej kwestii odniósł się kilkukrotnie w swoich wyrokach NSA. Jako przykład należy wskazać wyrok z dnia 27 kwietnia 1981 roku, SA 767/81, w którym NSA stwierdził, że

Instrukcja nr 5/68 Ministra Zdrowia i Opieki Społecznej z dnia 29 lutego 1968 r. w sprawie pomocy społecznej w formie świadczeń pieniężnych [...], jako akt adresowany do organów administracji państwowej i określający zasady, jakimi organy te powinny się kierować przy załatwianiu spraw, nie jest ogólnie obowiązującym aktem prawa materialnego $\mathrm{i}$ - jako taka — nie może stanowić podstawy prawnej decyzji administracyjnej ${ }^{46}$.

W przywołanym wyroku NSA uznał również, że u.o.s. zachowała moc obowiązującą na podstawie dekretu z dnia 12 października 1947 roku w sprawie mocy obowiązującej niektórych przepisów ustawodawstwa z zakresu opieki społecznej ${ }^{47}$. Problematykę obowiązywania przedwojennej ustawy o opiece społecznej NSA analizował także w wyroku z dnia 29 czerwca 1983 roku $^{48}$ i w wyroku z dnia 30 września 1988 roku $^{49}$.

Analizując pozycję świadczeniobiorców pomocy społecznej w okresie PRL, należy również zwrócić uwagę na praktykę organów administracji państwowej w tamtym okresie usankcjonowaną pismem Ministerstwa Zdrowia i Opieki Społecznej z dnia 9 stycznia 1981 roku, CP 00-30/80. W treści przedmiotowego pisma zalecono, aby z dniem 1 maja 1981 roku zaniechano wydawania decyzji administracyjnych w rozumieniu art. 104-113 ustawy z dnia 14 czerwca 1960 roku Kodeks postępowania administracyjnego ${ }^{50}$ o przyznaniu albo odmowie przyznania świadczenia pieniężnego z zakresu pomocy społecznej. Rekomendowano, żeby sprawy pomocy społecznej załatwiane były w drodze pisma skierowanego do osoby ubiegającej się o świadczenie, co w praktyce wyłączało możliwość sądowej kontroli decyzji wydawanych w sprawach pomocy społecznej ${ }^{51}$. Ten stan rzeczy trwał do momentu uchwalenia u.p.s.d., która na powrót wprowadziła katalog świadczeń z zakresu pomocy społecznej do systemu źródeł prawa powszechnie obowiązującego i umocniła pozycję prawną świadczeniobiorców pomocy społecznej.

\section{Wnioski}

Podsumowując: należy podkreślić, że w okresie powojennym systematycznie następowała dezorganizacja przedwojennej instytucji opieki społecznej ${ }^{52}$,

\footnotetext{
46 Wyrok NSA z dnia 27 kwietnia 1980 roku, SA 767/81, CBOSA.

47 Ibidem.

48 Wyrok NSA z dnia 29 czerwca 1983 roku, SA/Wr 290/83, CBOSA.

49 Wyrok NSA z dnia 30 września 1988 roku, I SA 1458/87.

${ }^{50}$ Dalej: k.p.a.

51 M. Mincer, op. cit., s. 85.

52 J. Staręga-Piasek, Pomoc społeczna wczoraj, dziś, jutro, „Pomoc Społeczna” 1993, nr 9, s. 1.
} 
wprowadzane były liczne zmiany w jej systemie, jak również nastąpiło osłabienie pozycji prawnej jej świadczeniobiorców. Instytucja opieki społecznej, uznana w początkowym okresie PRL za wrogą ideologicznie, przetrwała z licznymi zmianami przez cały okres powojenny. Opierała się jednak na niewłaściwej podstawie prawnej, a dodatkowo mocą Konstytucji PRL wprowadzone zostało pojęcie pomocy społecznej w miejsce opieki społecznej. Przez cały okres PRL formalnie obowiązywała u.o.s., jednak w praktyce nie była ona stosowana, a świadczenia pomocy społecznej przyznawane były na podstawie aktów prawa powielaczowego, co powodowało, że świadczeniobiorcy pozbawieni zostali prawnej możliwości obrony swoich praw przed NSA ${ }^{53}$.

Ten stan rzeczy trwał do 1989 roku. Dopiero w 1990 uchwalona została nowa ustawa o pomocy społecznej, która w 2004 została zastąpiona przez obecnie obowiązującą u.p.s. Stało się to możliwe dzięki zmianom ustrojowym, które zaszły w Polsce po 1989 roku. Ich wyrazem była zmiana jakościowego podejścia do instytucji pomocy społecznej jako doniosłej sfery działalności już nie administracji państwowej, a administracji publicznej, i ważnego elementu polityki społecznej państwa.

\section{Bibliografia}

Brenk M., System opieki społecznej w okresie Polski Ludowej (lata 1944-1989). Zarys problematyki, „Biuletyn Historii Wychowania” 2017, nr 37.

Cendrowicz D., Sytuacja administracyjnoprawna adresata świadczeń z zakresu pomocy społecznej, Wrocław 2017.

Karczewski M., [bez tytułu], „Opiekun Społeczny” 1974, nr 2.

Kluzowa K., Historia pracy socjalnej na łamach „Pracy Socjalnej”, [w:] Z zagadnień historii pracy socjalnej w Polsce, red. A. Małek, K. Slany, I. Szczepaniak-Wiech, Kraków 2006.

Kokoszkiewicz A., Opieka społeczna jako zadanie państwa. Studium teoretycznoprawne, Lublin 2015.

Langrod J.S., Praca i ubezpieczenie społeczne, [w:] K.W. Kumaniecki, J.S. Langrod, S. Wachholz, Zarys ustroju, postępowania i prawa administracyjnego w Polsce, Kraków-Warszawa 1939.

Lipowicz I., Samorząd terytorialny jako podmiot administracji świadczacej, „Ruch Prawniczy, Ekonomiczny i Socjologiczny" 2015, z. 3.

Mincer M., Pomoc społeczna jako instytucja prawna, „Nowe Prawo” 1982, nr 1.

Miruć A., O istocie pomocy społecznej, „Administracja. Teoria. Dydaktyka. Praktyka” 2006, nr 4 (5).

Nitecki S., Prawo do pomocy spolecznej w polskim systemie prawnym, Warszawa 2008.

Sałustowicz P., Pomoc społeczna w wybranych krajach Unii Europejskiej, Warszawa 2009.

Sierpowska I., Prawo pomocy spotecznej, Warszawa 2011.

Staręga-Piasek J., Pomoc społeczna wczoraj, dziś, jutro, „Pomoc Społeczna” 1993, nr 9.

Stopka K., Zasada subsydiarności w prawie pomocy społecznej, Warszawa 2009.

Szurgacz H., Uwagi o ewolucji pomocy społecznej, „Praca i Zabezpieczenie Społeczne” 1987, nr 2.

Szurgacz H., Wstęp do prawa pomocy społecznej, Wrocław 1992.

${ }^{53}$ M. Mincer, op. cit., s. 95. 


\section{Akty prawne}

Dekret z dnia 22 października 1947 roku w sprawie mocy obowiązującej niektórych przepisów ustawodawstwa z zakresu opieki społecznej (Dz.U. z 1947 r. Nr 65, poz. 389).

Instrukcja nr 5/68 Ministra Zdrowia i Opieki Społecznej z dnia 29 lutego 1968 roku w sprawie pomocy społecznej w formie świadczeń pieniężnych (Dz.Urz. MZiOS Nr 6, poz. 33 ze zm.).

Instrukcja nr 19/73 Ministra Zdrowia i Opieki Społecznej z dnia 27 lutego 1973 roku w sprawie organizowania pomocy społecznej w formie obiadów (Dz.Urz. MZiOS Nr 15, poz. 81 ze zm.).

Instrukcja Ministra Zdrowia i Opieki Społecznej z dnia 12 września 1979 roku w sprawie dziennych domów pomocy społecznej (Dz.Urz. MZiOS Nr 12, poz. 37).

Konstytucja Polskiej Rzeczypospolitej Ludowej uchwalona przez Sejm Ustawodawczy w dniu 22 lipca 1952 roku (Dz.U. z 1952 r. Nr 33, poz. 232).

Rozporządzenie Prezydenta Rzeczypospolitej Polskiej z dnia 29 czerwca 1924 roku w sprawie wykonywania opieki społecznej nad obywatelami polskimi, którzy w żadnej gminie Rzeczypospolitej Polskiej nie mają prawa do opieki trwałej, oraz ponoszenia wynikających stąd kosztów (Dz.U. z 1924 r. Nr 56, poz. 576).

Rozporządzenie Prezydenta Rzeczypospolitej z dnia 14 października 1927 roku o zwalczaniu żebractwa i włóczęgostwa (Dz.U. RP z 1927 r. Nr 92, poz. 823).

Rozporządzenie Prezydenta Rzeczypospolitej z dnia 6 marca 1928 roku o opiekunach społecznych i o komisjach opieki społecznej (Dz.U. RP z 1928 r. Nr 29, poz. 267).

Rozporządzenia Prezydenta Rzeczypospolitej z dnia 6 marca 1928 roku o rozgraniczeniu obowiązków opiekuńczych związków komunalnych (Dz.U. RP z 1928 r. Nr 26, poz. 232).

Rozporządzenie Rady Ministrów z dnia 9 maja 1958 roku w sprawie ustalenia stanowisk, kwalifikacji i uposażenia pracowników prezydiów rad narodowych (Dz.U. z 1958 r. Nr 33, poz. 149).

Ustawa z dnia 16 lipca 1923 roku o opiece społecznej (Dz.U. z 1923 r. Nr 92, poz. 726).

Ustawa z dnia 4 lutego 1950 roku o przekazaniu Ministrowi Zdrowia zakresu działania Ministra Pracy i Opieki Społecznej w przedmiocie opieki społecznej nad dziećmi do lat trzech oraz nad kobietami ciężarnymi i karmiącymi (Dz.U. z 1950 r. Nr 6, poz. 49).

Ustawa z dnia 20 marca 1950 roku o terenowych organach jednolitej władzy państwowej (Dz.U. z 1950 r. Nr 14, poz. 130).

Ustawa z dnia 13 kwietnia 1960 roku o utworzeniu Komitetu Pracy i Płac i o zmianie właściwości w dziedzinie ubezpieczeń społecznych i opieki społecznej (Dz.U. z 1960 r. Nr 20, poz. 119).

Ustawa z dnia 29 listopada 1990 roku o pomocy społecznej (Dz.U. z 1998 r. Nr 64, poz. 414).

Ustawa z dnia 12 marca 2004 roku o pomocy społecznej (Dz.U. z 2020 r., poz. 1876 ze zm.).

Uchwała Rady Ministrów nr 92 z dnia 5 marca 1959 roku w sprawie powołania instytucji opiekunów społecznych (M.P. Nr 32, poz. 145).

Zarządzenie Ministra Pracy i Opieki Społecznej z dnia 27 października 1959 roku o zakresie i trybie działania opiekunów społecznych (M.P. Nr 93, poz. 496 ze zm.).

\section{Orzecznictwo}

Wyrok NSA z dnia 27 kwietnia 1980 roku, SA 767/81, CBOSA.

Wyrok NSA z dnia 29 czerwca 1983 roku, SA/Wr 290/83, CBOSA.

Wyrok NSA z dnia 30 września 1988 roku, I SA 1458/87, CBOSA. 